Ann. Acad. Med. Siles. (online) 2020; 74: 166-180

eISSN 1734-025X

DOI: $10.18794 /$ aams/117864

PRACA POGLĄDOWA

REVIEW

\title{
Stress and cancer
}

\author{
Stres i nowotwór \\ Jadwiga Jośko-Ochojska1 (D), Ryszard Brus² \\ ${ }^{1}$ Department of Environmental Medicine and Epidemiology, Faculty of Medical Sciences, \\ Medical University of Silesia, Katowice, Poland \\ ${ }^{2}$ High School of Strategic Planning, Dabrowa Górnicza, Poland
}

\begin{abstract}
Scientific research has shown that during stress, the secretion of hormones and neurotransmitters in the brain, etc. is definitely stronger and longer lasting when persons are convinced that they cannot cope with the requirements of a stressful situation, i.e. they are in a state of uncontrolled stress. The main indicator of this condition is a long-term increase in the concentration of stress hormones in the blood. The higher the catecholamine concentration, the more DNA damage, the more cells undergoing tumour transformation, the larger the tumour and the more advanced the disease. Catecholamines also narrow blood vessels, which leads to an increase in VEGF expression, responsible for an increase in angiogenesis, and hence tumour growth and tumour metastasis. Cortisol contributes to inhibition of the immune system and changes in the central nervous system. Under uncontrolled stress, telomeres are shortened, which is another reason for shortening life expectancy. It has also been proven that stress and trauma are inherited in subsequent generations in the mechanism of epigenetic inheritance. Despite epigenetic predispositions to develop various malignancies, including ovarian, stomach and colorectal cancer, people can move from uncontrolled to controlled stress in a particular situation, even though the situation itself does not change. This is a breakthrough message. During cancer, the transition to controlled stress definitely supports therapy, increasing your chances of survival or even recovery. The most common condition for taking control of stress is to change your current lifestyle.
\end{abstract}

\section{KEY WORDS}

stress, cancer, catecholamines, glucocorticosteroids, VEGF, angiogenesis, telomeres, epigenetic inheritance

\section{STRESZCZENIE}

Badania naukowe dowiodły, że w czasie stresu wydzielanie hormonów, neuroprzekaźników w mózgu itp. jest zdecydowanie silniejsze i trwa dłużej, zwłaszcza jeśli człowiek jest przekonany, że nie będzie w stanie sprostać wymaganiom sytuacji stresowej, czyli pozostaje w stanie stresu niekontrolowanego. Głównym wskaźnikiem tego stanu jest długo trwający przyrost stężenia hormonów stresu we krwi. Im większe stężenie katecholamin, tym więcej uszkodzeń DNA, więcej komórek ulegających transformacji nowotworowej, większy guz i bardziej zaawansowana choroba. Katecholaminy ponadto zwężają naczynia krwionośne, co przyczynia się do wzrostu ekspresji czynnika VEGF, który zwiększa angiogenezę, wzrost guza i przerzuty nowotworowe. Kortyzol przyczynia się do hamowania układu immunologicznego i zmian w ośrodkowym układzie nerwowym. W stresie niekontrolowanym skróceniu ulegają telomery, które są kolejną przyczyną skrócenia długości życia. Dowiedziono także, że stres i trauma są dziedziczone w kolejnych pokoleniach

Received: 03.12.2019 Revised: 02.01.2020 Accepted: 04.02.2020 Published online: 25.09.2020

Address for correspondence: Prof. dr hab. n. med. Jadwiga Jośko-Ochojska, Katedra i Zakład Medycyny i Epidemiologii Środowiskowej, Wydział Nauk Medycznych, Śląski Uniwersytet Medyczny w Katowicach, ul. Jordana 19, 41-808 Zabrze, Polska, tel. +48 32 509 468 426, e-mail: jadwigajosko@gmail.com Copyright @ Śląski Uniwersytet Medyczny w Katowicach www.annales.sum.edu.pl 
w mechanizmie dziedziczenia epigenetycznego. Pojawiają się wtedy predyspozycje epigenetyczne do zachorowania na różne nowotwory złośliwe, w tym raka jajnika, żołądka, jelita grubego. W konkretnej sytuacji można jednak przejść ze stresu niekontrolowanego do kontrolowanego, mimo że sama sytuacja się nie zmienia, i to jest wiadomość przełomowa. W trakcie choroby nowotworowej wejście w stan stresu kontrolowanego zdecydowanie wspomaga terapię, zwiększając szansę na przeżycie lub nawet wyzdrowienie. Najczęściej warunkiem przejęcia kontroli nad stresem jest zmiana dotychczasowego stylu życia. Radzenie sobie ze stresem, aktywność ruchowa i zdrowe odżywianie się są w stanie nawet doprowadzić do zmian na poziomie epigenomu, a badania naukowe dowodzą, że możemy wtedy uporać się z licznymi odziedziczonymi predyspozycjami, zmniejszając prawdopodobieństwo zachorowania na nowotwory złośliwe.

\section{SŁOWA KLUCZOWE}

stres, nowotwór, katecholaminy, glikokortykosteroidy, VEGF, angiogeneza, telomery, dziedziczenie epigenetyczne

\section{INTRODUCTION}

Long-term uncontrolled stress, anxiety and traumatic events lead to such psychological and somatic changes in the body, often ending with a chronic disease, including a neoplastic disease. The success of treatment in such a case depends largely on the patient's approach. Many physicians reiterate: "Stress can't cause cancer." However, it should be noted that, among others, chronic stress is one of its main (many) causes. It also contributes to rapid progression of the disease, cancer metastases and patient death (Fig. 1).

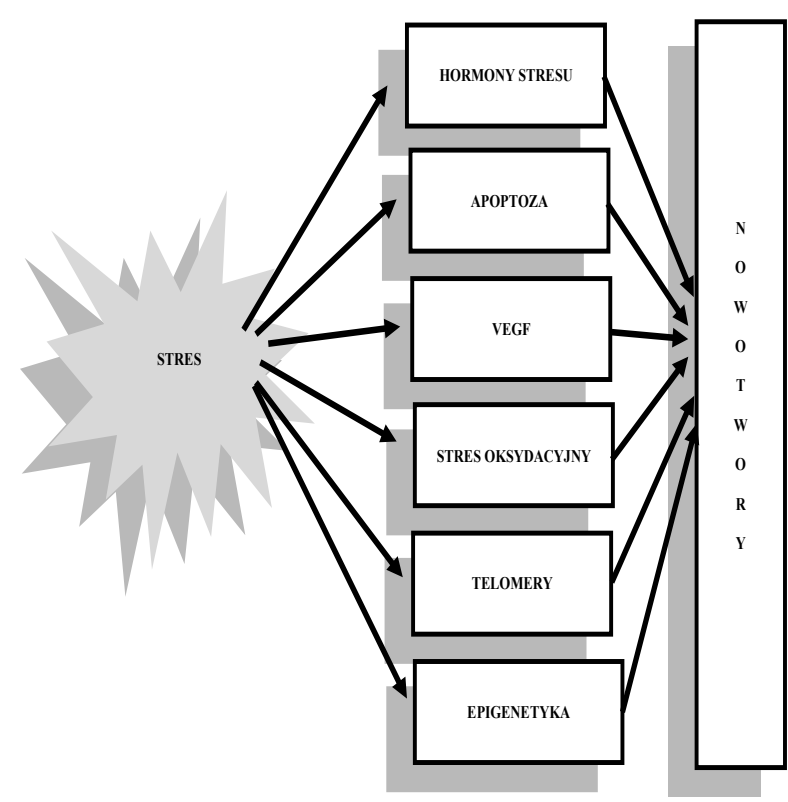

Ryc. 1. Powstawanie chorób nowotworowych na skutek stresu. Opracowanie własne.

Fig. 1. Emergence of cancer due to stress. Authors' own study.

Research on the mechanisms of stress in the human body have made great progress in recent years. The argument: "We all feel stress so why we should concern ourselves with it" is no longer defensible because in the face of genetic and epigenetic studies and the latest methods of brain imaging, it has transpired that we are able to control stress, and thus no longer succumb to its negative effects.

Short-term stress, "eustress", does not do much harm, as the physiological changes caused by it in the form

\section{WSTĘP}

Długotrwały, niekontrolowany stres, lęk, przeżycia traumatyczne doprowadzają do takich zmian psychicznych i somatycznych w organizmie, że niejednokrotnie kończą się chorobą przewlekłą, w tym chorobą nowotworową. Powodzenie leczenia w takim przypadku w dużej mierze zależy od podejścia pacjenta.

Wielu lekarzy powtarza, że „stres nie może wywołać raka”. Należy jednak podkreślić, że przewlekły stres, spośród wielu innych czynników, jest jedną z jego głównych przyczyn. Prowadzi także do szybkiego rozwoju choroby, przerzutów nowotworowych i zgonu pacjenta (ryc. 1).

W badaniach naukowych nad mechanizmami działania stresu w organizmie człowieka poczyniono w ciągu ostatnich lat ogromne postępy. Powiedzenie „Stres mamy wszyscy, po co się nim zajmować?" - już nie ma racji bytu, bowiem w obliczu badań genetycznych, epigenetycznych i najnowszych metod obrazowania mózgu okazało się, że jesteśmy w stanie kontrolować go, a tym samym nie ulegać już jego negatywnemu działaniu.

Krótki stres, zwany „eustresem”, nie przynosi większych szkód, bowiem zmiany fizjologiczne nim spowodowane, w postaci wzrostu stężenia hormonów stresu (adrenaliny, noradrenaliny, glikokortykosteroidów itd.) i osłabienia działania układu odpornościowego, powracają do normy po około 3 dniach.

Sytuacja staje się poważna dopiero wówczas, gdy stres działa przewlekle. Wywołuje on bardzo duże zmiany, które mogą doprowadzić do ciężkich chorób, a nawet śmierci organizmu. Negatywne skutki stresu zależą jednakże przede wszystkim od tego, czy posiadamy nad nim kontrolę, czy też poddajemy się mu bezradnie [1]. W 1971 r. Mason wyraźnie odróżnił stres kontrolowany od niekontrolowanego [2]. Ten podział jest najważniejszym podziałem stresu i powinien być znany nie tylko każdemu lekarzowi, lecz także każdemu człowiekowi. Stwierdzono bowiem, że wydzielanie hormonów, neuroprzekaźników w mózgu, neuromodulatorów itd. w czasie stresu jest zdecydowanie silniejsze i dłużej trwające, jeśli człowiek jest przekonany, że sobie nie poradzi, co oznacza, że znajduje się w stanie stresu niekontrolowanego. Często mówimy wtedy: „Nie mam wyjścia”, „Czuję się bezradna w tej sytuacji”, „Muszę tak działać”, „Nie da się już nic zrobić”, „To już ko- 
of an increase in the concentration of stress hormones (adrenaline, noradrenaline, glucocorticosteroids, etc.) and weakening of the immune system revert to normal within approx. 3 days.

The situation is serious only when we are dealing with chronic stress. In such a case, it causes enormous changes, which can lead to severe diseases and even death. However, the negative effects of stress depend primarily on whether we have control over it or succumb to it helplessly [1].

In 1971, Mason made a clear distinction between controlled and uncontrolled stress [2]. This division of stress is the most important one and should be known not only to every physician, but also to every other person. It was found that the secretion of hormones, neurotransmitters in the brain, neuromodulators, etc. during stress is definitely stronger and lasts longer when a person is convinced that they are unable to do something, in other words, when they are in a state of uncontrolled stress. In such a situation, we often say: "I have no choice", "I feel helpless in this situation", "I have to act like this", "There's nothing you can do", "It's over". The negative effects of stress occur when an acting stimulus is judged to be insurmountable, as causing danger or potentially leading to it. A positive action, or even mobilising life activity, can have a stimulus that is judged to be possible to overcome. Then we convert the expression "I must" to "I want" or "I can", we look for ways out of the stressful situation, we use different methods of dealing with stress on a daily basis, we are convinced that we have an influence on our lives. Then we are dealing with so-called controlled stress.

In a specific situation, one can thus switch from uncontrolled stress to controlled one, even though the situation itself does not change. This is breakthrough news since it means that when we are taking care of a paralysed family member, have a disabled child, work with toxic people, etc., we can still protect ourselves from the negative effects of stress, have control over our health, feel satisfied with life and can be happy $[1,3]$. This is a tool, a protective shield against the harmful effects of chronic stress.

The knowledge of stress is intrinsic to neoplastic diseases. As early as in antiquity, Hippocrates and Galen empirically stated that melancholy women (today we would say - women with depressive disorders) are more likely to develop breast cancer than sanguine women (i.e. open to people, emotionally stable, creative) [4]. Nowadays, we return to Galen's observations since, on the basis of scientific research, we have evidence that very strong life stressors can cause cancer development [5]. For instance, stress-induced neurotransmitters and hormones (including dopamine, serotonin, adrenaline, noradrenaline, acetylcholine and glucocorticosteroids) can change the microenvironment of a tumour and niec". Negatywne skutki stresu występują wówczas, gdy działający bodziec oceniany jest jako niemożliwy do pokonania, mogący spowodować zagrożenie lub je powodujący. Działanie pozytywne lub wręcz mobilizujące aktywność życiową może mieć ze sobą bodziec oceniany jako możliwy do przezwyciężenia. Wtedy zamieniamy słowo „muszę” na „chcę lub mogę”, szukamy dróg wyjścia, stosujemy różne metody radzenia sobie ze stresem na co dzień, jesteśmy przekonani, że mamy wpływ na swoje życie. Znajdujemy się wtedy W stanie stresu kontrolowanego.

W konkretnej sytuacji można więc przejść ze stresu niekontrolowanego do kontrolowanego, mimo że sama sytuacja się nie zmienia. To jest wiadomość przełomowa, oznacza bowiem, że mimo iż opiekujemy się sparaliżowanym członkiem rodziny, mamy dziecko niepełnosprawne, pracujemy w otoczeniu toksycznych osób itd., możemy chronić się przed negatywnymi skutkami stresu, mamy wpływ na swoje zdrowie, możemy czuć satysfakcję z życia i być szczęśliwymi osobami [1,3]. To jest narzędzie, tarcza obronna przeciw szkodliwym skutkom przewlekłego stresu.

Wiedza na temat stresu wiąże go nieodłącznie $\mathrm{z}$ chorobami nowotworowymi. Już w starożytności Hipokrates i Galen stwierdzali empirycznie, że kobiety melancholijne (dzisiaj powiedzielibyśmy - mające zaburzenia depresyjne) częściej zapadają na raka piersi niż kobiety sangwiniczne (czyli otwarte, stabilne emocjonalnie, kreatywne) [4].

W dzisiejszych czasach wracamy do spostrzeżeń Galena, gdyż dzięki badaniom naukowym uzyskaliśmy dowody na to, że bardzo silne stresory życiowe mogą prowadzić do rozwoju raka [5]. Na przykład, indukowane stresem neuroprzekaźniki i hormony, w tym dopamina, serotonina, adrenalina, noradrenalina, acetylocholina i glikokortykosteroidy, mogą zmieniać mikrośrodowisko guza i oddziaływać na nowotwór poprzez wpływ na komórki odpornościowe, komórki rakowe i angiogenezę w różnych nowotworach.

Lillberg wraz z zespołem przebadał 10808 kobiet i dowiódł, że istnieje związek między stresującymi wydarzeniami życiowymi a ryzykiem raka piersi [6].

W 2018 r. przeprowadzono badania dotyczące rozwoju trzech groźnych nowotworów złośliwych - raka jelita grubego, przełyku i płuca. Badania miały na celu sprawdzenie, czy istnieje związek między stresem w pracy a ryzykiem powstania raka. Przebadano 281290 mieszkańców Ameryki Północnej i Europy. W analizie uwzględniono różne czynniki, które mogą wpływać na pojawienie się i rozwój nowotworu złośliwego, w tym m.in. palenie papierosów, picie alkoholu, wskaźnik masy ciała, niską aktywność fizyczną. Okazało się, że stres w pracy zwiększał ryzyko zachorowania na raka przełyku o $112 \%$, raka jelita grubego o $36 \%$ oraz raka płuca o $24 \%$ [7]. 
affect the neoplasm by affecting immune cells, cancer cells and angiogenesis in different cancers.

Lillberg and her research team examined 10,808 women and proved that there was a link between stressful life events and the risk of breast cancer [6].

In 2018, research was conducted on the development of three dangerous malignancies - colorectal, oesophageal and lung cancer. The research was aimed at verifying whether there was a link between stress at work and a cancer risk. 281290 inhabitants of North America and Europe were examined. The analysis took into account various factors that may affect the occurrence and development of malignancy, including cigarette smoking, alcohol consumption, body mass index (BMI) and low physical activity. It turned out that stress at work increased the risk of oesophageal cancer by $112 \%$, colorectal cancer - by $36 \%$ and lung cancer - by $24 \%$ [7].

\section{STRESS, STRESS HORMONES AND NEOPLASTIC DISEASE}

\section{Catecholamines (adrenaline and noradrenaline)}

Numerous scientific studies around the world have proved that stress hormones affect cancer formation, cancer cell invasion, tumour growth, cancer metastases and survival. It has been found that in uncontrolled stress, there are much higher concentrations of adrenaline and noradrenaline secreted by the sympathetic nervous system and suprarenal glands than in controlled stress. These hormones modify many physiological functions (elevate the heart rate and blood pressure, dilate the pupils, increase blood glucose, etc.), contributing, among others, to diabetes, hypertension, etc.

It has also been scientifically proved that the higher adrenaline and noradrenaline levels, the larger the tumour and the more advanced the disease $[5,8,9,10,11,12]$.

Epidemiological studies concerning the link between chronic stress and cancer proved that stressful life events were closely related to shorter survival of cancer patients [13]. For instance, it was found that catecholamine signalling increases the metastatic phenotype of prostate cancer cells [14].

Recent studies concerning the links between catecholamine and neoplastic diseases point to the fact that adrenaline or noradrenaline bind to $\beta$-adrenergic receptors, which leads to increased levels of cyclic AMP (cAMP) that induce protein kinase A (PKA) activity. PKA may then phosphorylate such proteins as: CREB (CRE binding protein) - a transcription factor activated in response to cAMP, ATF (activating transcription factor), GATA1 (transcription factor binding to guanine-adenine-thymine-adenine sequences in gene regulatory regions) and proteins from the Src tyrosine kinase family. The above-mentioned transcription factors increase the activity of pro-cancer proteins stimulating tumour growth, invasion, and migration of its cells as well as angiogenesis [15].

Further studies prove yet another mechanism of the action of catecholamines: they act on DNA in a cell in

\section{STRES, HORMONY STRESU I CHOROBA NOWOTWOROWA}

\section{Katecholaminy (adrenalina i noradrenalina)}

Liczne badania naukowe na całym świecie dowiodły, że hormony stresu wpływają na powstawanie raka, inwazję komórek nowotworowych, wzrost guza, przerzuty nowotworowe i długość przeżycia. Dowiedziono, że w stresie niekontrolowanym występują o wiele wyższe stężenia adrenaliny i noradrenaliny wydzielane przez układ współczulny i nadnercza niż w stresie kontrolowanym. Hormony te zmieniają wiele funkcji fizjologicznych (powodują wzrost ciśnienia krwi, przyspieszenie akcji serca, rozszerzenie źrenic, podwyższenie stężenia glukozy we krwi itd.), przyczyniając się między innymi do powstania cukrzycy, nadciśnienia itp. Potwierdzono także naukowo, że im większe stężenie adrenaliny i noradrenaliny, tym większy guz i bardziej zaawansowana choroba $[5,8,9,10,11,12]$.

Badania epidemiologiczne dotyczące związku przewlekłego stresu z zachorowaniem na raka potwierdziły, że stresujące wydarzenia życiowe wiążą się ściśle z krótszym przeżyciem pacjentów chorych na raka [13]. Odkryto na przykład, że sygnalizacja katecholaminowa zwiększa fenotyp przerzutowy komórek raka prostaty [14].

W najnowszych badaniach dotyczących związków katecholamin $\mathrm{z}$ chorobami nowotworowymi zwraca się uwagę na fakt, że adrenalina lub noradrenalina wiążą się z receptorami $\beta$-adrenergicznymi, co powoduje zwiększenie poziomów cyklicznego AMP (cAMP), które indukują aktywność kinazy białkowej A (PKA). PKA może następnie fosforylować takie białka, jak: CREB (białko wiążące CRE; CRE binding protein) czynnik transkrypcyjny aktywowany w odpowiedzi na cAMP, ATF (czynnik transkrypcyjny; activating transcription factor 1), GATA1 (czynnik transkrypcyjny wiążący się $\mathrm{z}$ sekwencjami guanina-adenina-tymina-adenina w regionach regulatorowych genów) i białka z rodziny kinaz tyrozynowych Src. Powyższe czynniki transkrypcyjne zwiększają aktywność białek pronowotworowych stymulujących wzrost guza, inwazję oraz migrację jego komórek, a także proces angiogenezy [15].

Kolejne badania dowodzą istnienia jeszcze innego mechanizmu działania katecholamin - działają one na DNA w komórce w ten sposób, że im większe stężenie adrenaliny i noradrenaliny, tym więcej uszkodzeń DNA i więcej komórek nowotworowych. Potwierdzają to badania $\mathrm{z}$ wykorzystaniem hodowli in vitro mysich fibroblastów, które na skutek inkubacji z adrenaliną lub noradrenaliną wykazywały wzrost liczby uszkodzeń DNA, czego efektem był wyższy odsetek komórek ulegających transformacji nowotworowej $[16,17]$.

W 2010 r. po raz pierwszy podano, że stosowanie antagonistów receptorów $\beta$-adrenergicznych w układzie współczulnym, po zdiagnozowaniu choroby nowotworowej, zmniejsza prawdopodobieństwo nawrotu choroby i poprawia przeżycie pacjentów z rakiem piersi [18]. 
such a way that the higher the adrenaline and noradrenaline levels, the more DNA damage, and more cancer cells. This is proved by studies using mouse fibroblasts in vitro cell culture system, which due to incubation with adrenaline or noradrenaline showed an increase in the amount of DNA damage, the result of which was a higher percentage of cells undergoing neoplastic transformation $[16,17]$.

In 2010, for the first time, it was reported that the use of $\beta$-adrenergic receptor antagonists in the sympathetic nervous system, after the diagnosis of a neoplastic disease, reduced the likelihood of relapse and improved survival in patients with breast cancer [18]. Another proof that catecholamines contribute to the development of cancer are studies in which a decrease in the prevalence of cancer is observed in patients taking $\beta$-adrenergic receptor antagonists due to treatment of other diseases $[15,19]$.

In total, these data indicate that stress may affect cancer biology in humans by activating the pro-metastatic catecholamine pathway [20].

\section{Dopamine}

The effect of dopamine on neoplastic diseases is also of great importance. This link is not only a precursor of adrenaline and noradrenaline production, but also acts independently in the brain as a neurotransmitter. In contrast to adrenaline and noradrenaline, it is responsible for muting the effects of stress reaction in the body. It has been found that dopamine can also act as an endogenous suppressor of the process of carcinogenesis, limiting the growth of tumours, which is mainly done through the inhibition of angiogenesis [16,21]. In recent years, the interest in new phenothiazine derivatives - which have so far been used to treat schizophrenia, mania, or psychoses of various origins - has significantly increased. In addition to neuroleptic effects (blocking D2 dopaminergic receptors in the central nervous system), they also exhibit antimicrobial, antiviral, antiprotozoal, antiprion, anthelmintic properties and - most importantly - anticancer properties. Their anticancer effect is mainly based on antiproliferative, antioxidant and immunomodulating effects [22,23,24]. Special attention should be paid to the study involving over 100,000 subjects, which showed that patients with schizophrenia, who were treated with neuroleptics, were less likely to develop cancer when compared to subjects who did not take antipsychotic medications [25].

On the other hand, depending on individual susceptibility to stress and anxiety, different dopamine levels are secreted in the reward system in the brain. As a result, a dysfunction of the dopaminergic system and weakening of motivational processes may occur, which may cause a decrease in motivation to undertake cancer treatment and acceleration of disease progression $[26,27,28]$.
Kolejnym dowodem na udział katecholamin w rozwoju raka są badania, w których obserwuje się zmniejszenie częstości występowania nowotworu u pacjentów przyjmujących antagonistów receptorów $\beta$-adrenergicznych $\mathrm{z}$ powodu leczenia innych chorób $[15,19]$.

Łącznie dane te wskazują, że stres może wpływać na biologię raka u ludzi poprzez aktywację prometastatycznego szlaku katecholaminowego [20].

\section{Dopamina}

Wpływ dopaminy na choroby nowotworowe również ma istotne znaczenie. Związek ten jest nie tylko prekursorem wytwarzania adrenaliny i noradrenaliny, ale działa także samodzielnie w mózgu jako neuroprzekaźnik. W przeciwieństwie do adrenaliny i noradrenaliny odpowiada za wyciszanie skutków reakcji stresowej w organizmie. Wykazano że, dopamina może działać jako endogenny supresor procesu karcynogenezy, ograniczając wzrost guzów nowotworowych, co odbywa się głównie za pośrednictwem inhibicji procesu angiogenezy $[16,21]$.

W ostatnich latach znacznie wzrosło zainteresowanie nowymi pochodnymi fenotiazyny, które do tej pory były stosowane w leczeniu schizofrenii, manii czy też psychoz o różnym podłożu. Oprócz działania neuroleptycznego (blokującego receptory dopaminergiczne D2 w ośrodkowym układzie nerwowym) wykazują także właściwości przeciwbakteryjne, przeciwwirusowe, przeciwpierwotniakowe, przeciwprionowe, przeciwrobacze... i co najważniejsze - przeciwnowotworowe. Ich działanie antyrakowe opiera się głównie na działaniu antyproliferacyjnym, antyoksydacyjnym i immunomodulującym [22,23,24].

$\mathrm{Na}$ szczególną uwagę zasługuje badanie obejmujące ponad 100000 osób, w którym wykazano, że chorzy na schizofrenię, przyjmujący leki neuroleptyczne, chorowali rzadziej na nowotwory niż osoby, które nie zażywały neuroleptyków [25].

Z drugiej strony jednak można zauważyć, że w zależności od osobniczej podatności na stres i lęk wydzielane są różne stężenia dopaminy w mózgu w układzie nagrody. W efekcie może dojść do dysfunkcji układu dopaminergicznego i osłabienia procesów motywacyjnych, czego skutkiem byłby spadek motywacji do podjęcia leczenia choroby nowotworowej i przyspieszenie jej progresji [26,27,28].

\section{Glikokortykosteroidy (kortyzol, kortykosteron)}

Podobnie jak w przypadku katecholamin, w stresie niekontrolowanym występują o wiele wyższe stężenia glikokortykosteroidów (głównie kortyzolu), niż w stresie kontrolowanym. O ile dobowa produkcja kortyzolu wynosi w warunkach relaksu około $10-30 \mathrm{mg}$, to w stresie wzrasta nawet dziesięciokrotnie! Tak olbrzymie stężenia hormonu, który wykazuje działanie na cały metabolizm organizmu, musi odbić się negatywnie. 


\section{Glucocorticosteroids (cortisol, corticosterone)}

Similarly, as with catecholamines, there are much higher levels of glucocorticosteroids (mainly cortisol) in uncontrolled stress than in controlled. While daily cortisol production is approx. 10-30 mg under relaxing conditions, the production of cortisol under stress increases up to 10 times. Such huge concentrations of the hormone - which has an effect on the entire metabolism of the body - must have a negative impact.

\section{The effect of glucocorticosteroids on the immune system}

Dozens of animal and human studies have shown that elevated cortisol levels during stress inhibit the immune system, and thus contribute to many various diseases. Non-specific immunity - as well as specific, cellular and humoral- is then inhibited.

In neoplastic diseases, this is of particular importance because everyone around the world has cancer cells in their body and, among others, it will largely depend on the proper functioning of our immune system whether we develop cancer or not. This is why we are biologically equipped with the immune system - its task is to recognise "foreign" cells and protect us from them.

The combination of cortisol with the cell receptor stimulates the secretion of certain proinflammatory interleukins, such as:

- IL-1 (interleukin 1) - rapid secretion under stress, IL-1 causes depressive states which disrupt the treatment process, as they demotivate patients to struggle with the disease as well as take away hope for cure.

- IL-6 (interleukin 6) - rapid secretion under stress, IL-6 plays an important role in the pathogenesis and development of cancer, facilitating tumour growth by inhibiting the process of cancer cell apoptosis, the induction of angiogenesis and inactivation of tumour-suppressor gene p53 [25]. Recent studies stress that elevated IL-6 levels are also associated with depression, loss of appetite, fatigue, and pain in examined patients with lung and pancreatic cancer [30].

- IL-8 (interleukin 8) - rapid secretion under stress, IL-8 is a proinflammatory chemokine, participating in many pathological processes. In neoplastic diseases, chemokine has been found to have a double effect: protective - when it accumulates neutrophils that destroy cancer cells; and injurious - when it releases angiogenic factors that increase angiogenesis $[31,32]$.

\section{T lymphocytes, NK cells}

Under uncontrolled stress, the suprarenal medulla and adrenal cortex secrete excess catecholamines and glucocorticosteroids. These hormones combine with the receptors of immune cells (e.g. lymphocytes, monocytes, macrophages, and granulocytes) and modify their

\section{Działanie glikokortykosteroidów na układ immunologiczny}

Dziesiątki badań przeprowadzanych na zwierzętach i ludziach dowodzą, że podwyższone stężenia kortyzolu w sytuacji stresu hamują układ odpornościowy i przyczyniają się $\mathrm{w}$ ten sposób do zachorowania na wiele różnych chorób. Blokowana jest wtedy odporność nieswoista oraz swoista komórkowa i humoralna. W chorobach nowotworowych ma to szczególne znaczenie, bowiem ludność całego świata posiada komórki nowotworowe w swoich organizmach i między innymi od prawidłowego działania układu odpornościowego w dużej mierze będzie zależało, czy dana osoba zachoruje na raka czy nie. Po to biologicznie jesteśmy wyposażeni w układ odpornościowy, aby rozpoznawał „obce” komórki i bronił nas przed nimi.

Połączenie się kortyzolu z receptorem w komórce powoduje pobudzenie wydzielania niektórych prozapalnych interleukin, jak na przykład:

- IL-1 (interleukina 1) jest gwałtownie wydzielana w warunkach stresu, wywołuje stany depresyjne, które zaburzają proces leczenia, bowiem demotywują pacjentów do walki z chorobą i odbierają nadzieję na wyleczenie.

- IL-6 (interleukina 6) jest gwałtownie wydzielana w warunkach stresu, odgrywa ważną rolę w patogenezie i rozwoju nowotworów, ułatwiając wzrost guza poprzez hamowanie procesu apoptozy komórek nowotworowych, indukcję angiogenezy i dezaktywację supresorowego genu p53 w obrębie guza nowotworowego [25]. W najnowszych badaniach podkreśla się, że podwyższone stężenia IL-6 mają także związek z depresją, brakiem apetytu, zmęczeniem i bólem u badanych pacjentów $\mathrm{z}$ rakiem płuc i trzustki [30].

- IL-8 (interleukina 8) jest gwałtownie wydzielana w warunkach stresu, jest chemokiną prozapalną, biorącą udział $\mathrm{w}$ wielu procesach patologicznych. W chorobach nowotworowych wykazano jej podwójne działanie, $\mathrm{z}$ jednej strony ochronne, gdy gromadzi neutrofile, które niszczą komórki nowotworowe, a z drugiej strony szkodliwe, kiedy uwalnia czynniki angiogenne, które zwiększają angiogenezę [31,32].

\section{Limfocyty T, komórki NK}

Pod wpływem niekontrolowanego stresu rdzeń i kora nadnerczy wydzielają w nadmiarze zarówno katecholaminy, jak i glikokortykosteroidy. Hormony te łączą się $\mathrm{z}$ receptorami komórek odpornościowych, m.in. limfocytów, monocytów, makrofagów i granulocytów, modyfikując ich funkcjonowanie, co osłabia działanie układu odpornościowego [33]. Pod wpływem glikokortykosteroidów dochodzi do upośledzenia funkcji komórek NK i limfocytów T, a to sprzyja przede wszystkim progresji choroby nowotworowej [34]. 
functioning, which weakens the immune system [33]. The effect of glucocorticosteroids impairs the function of NK cells and T lymphocytes, and this favours the progression of a neoplastic disease [34].

\section{The effect of glucocorticosteroids on the central nervous system}

Cortisol also plays a major role in the destructive effects on the brain [1]. Under uncontrolled stress, amygdala enlargement as well as neuronal atrophy in the prefrontal cortex and hippocampus occur. The effects are very serious since they usually lead to insomnia, hormonal imbalance, memory and mood disorders, as well as depression. Enlarged amygdalae increase anxiety and aggression. In such a state, sadness, anhedonia, depression, anxiety, and lack of motivation to eat healthycan make the best and most expensive cancer treatment in the world ineffective.

\section{STRESS, APOPTOSIS AND NEOPLASTIC DISEASE}

Apoptosis (Greek for 'leaf fall') is the process of programmed, suicidal death of a cell. It is a natural process by which used or damaged cells, such as cancer cells, are removed from the body.

Apoptosis occurs under physiological conditions, under the influence of a wide variety of factors. They trigger genetic programmes in a cell depending on the type of cell and stimulus. Through apoptosis, both superfluous cells and cells potentially harmful to the human body die; however, the characteristic of cancer is the acquired ability of cancer cells to avoid apoptosis [35]. Additionally, catecholamines participate in the process of apoptosis inhibition, contributing to an even longer survival of cancer cells and progression of the disease. In various experimental models of cancer in mice, as well as in patients with prostate cancer, it has been proven that in behavioural stress adrenaline activates signal pathways that lead to apoptosis inhibition, which is an important feature in the process of tumour growth and cancer metastases $[36,37,16]$.

The mechanism of apoptosis inhibition is performed by the combination of adrenaline with the $\beta 2$-adrenergic receptor, which results in a number of cellular transformations that consequently contribute to the release of anti-apoptotic proteins: Bcl-2 and Bcl-xl [38].

\section{STRESS, VEGF AND NEOPLASTIC DISEASE}

In order to form a tumour and survive, cancer cells must be well-vascularized. VEGF (vascular endothelial growth factor) is responsible for this in our body.

Alas, under uncontrolled stress, its expression is very high, and the mechanism of increase in expression is as follows: elevated adrenaline and noradrenaline levels under stress shrink the blood vessels, which re-
Działanie glikokortykosteroidów na ośrodkowy układ nerwowy

Udział kortyzolu w niszczącym działaniu na mózg jest bardzo istotny [1]. W niekontrolowanym stresie dochodzi do zaników neuronów w korze przedczołowej i hipokampie oraz powiększenia się jąder migdałowatych. Skutki tego działania są bardzo poważne, bo z reguły prowadzą do bezsenności, rozregulowania gospodarki hormonalnej ustroju, zaburzeń pamięci, nastroju i depresji. Powiększone jądra migdałowate wzmagają lęk i agresję. W takim stanie smutek, anhedonia, depresja, lęk i brak motywacji do odzyskania zdrowia mogą sprawić, że nawet najlepsze i najdroższe kuracje przeciwnowotworowe na świecie będą nieskuteczne!

\section{STRES, APOPTOZA I CHOROBA NOWOTWOROWA}

Apoptoza (gr. apoptosis - opadanie liści) jest procesem zaprogramowanej, samobójczej śmierci komórki, ale procesem naturalnym, dzięki któremu z organizmu usuwane są zużyte lub uszkodzone komórki, na przykład nowotworowe.

Apoptoza zachodzi w warunkach fizjologicznych pod wpływem bardzo różnorodnych czynników. Uruchamiają one w komórce programy genetyczne, zależnie od typu komórki oraz bodźca. W wyniku apoptozy umierają komórki zbędne i potencjalnie szkodliwe dla organizmu, jednak cechą raka jest nabyta zdolność komórek nowotworowych do unikania tego procesu [35]. Dodatkowo, katecholaminy biorą udział w hamowaniu apoptozy, przyczyniając się do jeszcze dłuższego przeżycia komórek nowotworowych i postępu choroby. $\mathrm{W}$ różnych modelach eksperymentalnych raka u myszy oraz pacjentów z rakiem prostaty dowiedziono, że w stresie behawioralnym adrenalina aktywuje szlaki sygnałowe, które prowadzą do zahamowania apoptozy, co jest ważną cechą $\mathrm{w}$ procesie wzrostu guza i przerzutów nowotworowych [16,36,37].

Mechanizm zahamowania apoptozy dokonuje się poprzez połączenie się adrenaliny $\mathrm{z}$ receptorem $\beta 2$-adrenergicznym, co prowadzi do szeregu przemian w komórce, które w efekcie przyczyniają się do uwolnienia antyapoptotycznych białek Bcl-2 i Bcl-xl [38].

\section{STRES, VEGF I CHOROBA NOWOTWOROWA}

Aby komórki nowotworowe mogły utworzyć guz i przeżyć, muszą być dobrze unaczynione. $\mathrm{O}$ to dba w naszym organizmie VEGF - naczyniowy czynnik wzrostu śródbłonka (vascular endothelial growth factor).

Niestety, w stresie niekontrolowanym jego ekspresja jest bardzo wysoka, a mechanizm jej wzrostu przebiega następująco: wzrost adrenaliny i noradrenaliny w stresie kurczy naczynia, co powoduje wydzielanie endoteliny-1 i niedotlenienie. Wtedy wydzielany jest czyn- 
sults in the secretion of endothelin-1 and hypoxia. Then a hypoxic-induced factor - 1 (HIF-1) - is secreted, which stimulates VEGF expression. VEGF accelerates angiogenesis, i.e. the formation of new blood vessels, on the basis of those that already exist. In this way, the tumour cells are well-vascularized and well-supplied with blood, the tumour grows quickly, and it provides cancer metastases to other organs in a short period of time. It turns out that VEGF expression under uncontrolled stress is much greater than under controlled stress, thus people with uncontrolled stress are characterised by faster progression of the disease; cancer metastases and death occur sooner [39,40].

It has also been found that stress-induced $\beta$-adrenergic signalling promotes cancer progression and metastases, mainly through increased angiogenesis, in animal models of breast cancer $[41,42]$.

Another hormone secreted under stress - oxytocin affects the secretion of VEGF. Recent studies have proved that chronic stress and related high levels of oxytocin, through actions increasing the VEGF expression, promote cancer metastases of melanoma. The authors believe that oxytocin is a newly discovered factor conducive to cancer metastases and therefore, a potential therapy goal for the fight against melanoma [43].

\section{STRESS, OXIDATIVE STRESS AND NEOPLASTIC DISEASE}

Chronic stress is one of the main factors in the formation of an increased number of free radicals, i.e. oxidative stress. It leads to disruption of the balance between free radicals (ROS) and antioxidants in the body. As long as this balance is maintained, the body functions properly. However, when the formation of free radicals increases or the antioxidant activity decreases, oxidative stress occurs.

An increasing amount of data shows the participation of ROS in neoplastic cellular transformation. Currently, the contribution of oxidative DNA damage to mutagenesis is fully taken into account. The appearance of a mutation in suppressor genes and/or oncogenes may lead to the initiation, promotion and progression of carcinogenesis. Its formation is caused by complex cellular mechanisms, including oncogenic signals, intense metabolism associated with constant proliferation, $\mathrm{mu}-$ tations in mitochondrial DNA and dysfunctions in the respiratory chain. High ROS concentrations in cancer cells may be responsible for the rapid rate of cell divisions, successive mutations in DNA and genome instability, as well as may lead to resistance to certain groups of drugs applied in anticancer therapy $[44,45,46]$.

The contribution of oxidative stress to the development of cancer also consists in maintaining an inflammatory microenvironment conducive to increased proliferation of cancer cells. Variations in the activity of transcription factors, such as the nuclear factor, NF- $\mathrm{B}$, AP-1, Nrf2, STAT3 and hypoxia-induced - HIF-1 $\alpha$, are observed. Moreover, the studies indicate the contribution of oxi- nik indukowany hipoksją - 1 (HIF-1), który pobudza ekspresję VEGF. Czynnik VEGF przyspiesza angiogenezę, czyli powstawanie nowych naczyń, na bazie już istniejących. W ten sposób komórki guza są dobrze unaczynione, dobrze ukrwione, guz szybko rośnie i w krótkim czasie daje przerzuty nowotworowe do innych narządów. Okazuje się, że ekspresja VEGF w stresie niekontrolowanym jest o wiele większa niż w kontrolowanym, stąd u osób w stresie niekontrolowanym następuje szybsza progresja choroby, szybciej dochodzi do przerzutów nowotworowych i zgonu $[39,40]$.

Wykazano także, że indukowana stresem sygnalizacja $\beta$-adrenergiczna promuje progresję raka i przerzuty W zwierzęcych modelach raka piersi, głównie poprzez zwiększoną angiogenezę [41,42].

Na wydzielanie VEGF wpływa jeszcze inny hormon wydzielany w stresie - oksytocyna. Najnowsze badania dowodzą, że przewlekły stres i związane z nim wysokie stężenia oksytocyny, poprzez działania zwiększające ekspresję VEGF, promują przerzuty nowotworowe czerniaka. Autorzy uważają, że oksytocyna jest nowo odkrytym czynnikiem sprzyjającym przerzutom nowotworowym, a zatem jest potencjalnym celem terapeutycznym w walce z czerniakiem [43].

\section{STRES, STRES OKSYDACYJNY I CHOROBA NOWOTWOROWA}

Przewlekły stres jest jednym z głównych czynników powstania zwiększonej liczby wolnych rodników, czyli stresu oksydacyjnego. Dochodzi wówczas do zakłóconej równowagi między wolnymi rodnikami (RFT) i antyoksydantami (przeciwutleniaczami) w organizmie. Dopóki ta równowaga jest zachowana, organizm funkcjonuje prawidłowo. Jednak gdy rośnie produkcja wolnych rodników lub spada aktywność antyoksydantów, dochodzi do stresu oksydacyjnego.

Coraz więcej danych wskazuje na udział RFT w transformacji nowotworowej komórek. Obecnie w pełni uwzględnia się udział oksydacyjnych uszkodzeń DNA $\mathrm{w}$ procesie mutagenezy. Wystąpienie mutacji w genach supresorowych i/lub onkogenach może prowadzić do inicjacji, promocji i progresji procesu kancerogenezy. Za jego powstawanie są odpowiedzialne złożone mechanizmy komórkowe obejmujące m.in.: sygnały onkogenne, intensywny metabolizm związany z ciągłą proliferacją, mutacje w DNA mitochondrialnym i dysfunkcje w łańcuchu oddechowym. Wysokie stężenie RFT w komórkach nowotworowych może odpowiadać za szybkie tempo podziałów komórkowych, kolejne mutacje w DNA i niestabilność genomu, a także prowadzić do oporności na pewne grupy leków stosowanych w terapii antynowotworowej $[44,45,46]$.

Udział stresu oksydacyjnego w rozwoju raka polega także na podtrzymywaniu mikrośrodowiska zapalnego sprzyjającego nasilonej proliferacji komórek nowotworowych. Obserwowane są zmiany w aktywności czynników transkrypcyjnych, takich jak czynnik jądrowy, 
dative stress to the regulation of the cascade of kinases belonging to the MAPK family [47].

Other studies prove that principles modified in DNA may be later one of the factors determining cancer metastases [48].

\section{STRESS, TELOMERES AND NEOPLASTIC DISEASE}

Under uncontrolled stress, the ends of chromosomes telomeres - become shorter, which is another cause of reduced life expectancy of people with cancer $[49,50]$. Telomeres are fragments of a chromosome located at its end and protect it from damage during duplication. If the chromosomes containing our genetic material are visible as threads, the telomeres are the ends of each chromosome thread from both its ends. They can be compared to aglets located on the ends of shoelaces. Aglets wear out over time and when they eventually fall apart, the shoelaces start to shred. It is similar with telomeres. Telomeres shorten with each cell division, whereas with each shortening of the telomere, the risk of carcinogenesis increases, and the cell ages. The older a person is, the shorter their telomeres are. The more intense the uncontrolled stress, the higher the probability of neoplastic diseases, shorter telomeres and reduced life expectancy $[1,50]$.

The length of telomeres is much affected by our emotions, traumas, post-traumatic stress disorder (PTSD), an unhealthy diet, etc. In 2017, a meta-analysis was conducted with 16,238 participants and it was found that the greater the stress in childhood, the shorter the telomeres in adulthood [51].

There is also evidence of opposite emotions - positive ones. The discovery of telomerase - an enzyme whose effect consists in reproducing telomeres - caused us to look differently at the contribution of positive emotions to cancer treatment. We have learnt so far that the more positive emotions and better relations with the family, the longer the telomeres were in children [52]. Positive emotions, meditation and physical activity cause, already after 3 months, an increase in telomerase by $30 \%$ and elongation of telomeres $[53,54]$. It should be noted that there is no drug in the world that would lead to similar effects.

However, when telomeres are too short, DNA damage may result in the production of non-functional proteins by a cell. Such proteins may become non-functional cells and eventually become cancer cells [55].

There is evidence that physical exercise leads to reduced telomere depletion and lowers the risk of developing cancer. This is done by two mechanisms: the reduction of oxidative stress and reduction of chronic inflammation. An opposite situation is in people already suffering from cancer: people undergoing anticancer treatment may suffer from a significant decrease in their quality of life, which may be the cause of a sedentary lifestyle and additionally lead to increased telomere exhaustion [56].
NF-кB, AP-1, Nrf2 i STAT3 oraz indukowany hipoksją HIF-1 $\alpha$. Badania wskazują ponadto na udział stresu oksydacyjnego w regulacji kaskady kinaz należących do rodziny MAPK [47].

Według innych doniesień zmodyfikowane zasady w DNA mogą być później jednym z czynników decydujących o przerzutach nowotworowych [48].

\section{STRES, TELOMERY I CHOROBA NOWOTWOROWA}

W stresie niekontrolowanym skróceniu ulegają końcówki chromosomów, tzn. telomery, które są kolejną przyczyną skrócenia długości życia osób chorujących na raka $[49,50]$.

Telomery są fragmentami chromosomu zlokalizowanymi na jego końcu i zabezpieczają go przed uszkodzeniem podczas kopiowania. Jeśli chromosomy zawierające nasz materiał genetyczny widoczne są jako nici, to telomery są zakończeniami każdej nici chromosomów z obu jej końców. Można je porównać do skuwek na końcach sznurowadeł. Skuwki sznurowadeł z czasem się zużywają i kiedy się w końcu rozpadną, wówczas sznurowadła zaczynają się strzępić. Podobnie jest z telomerami. Telomery skracają się podczas każdego podziału komórki, a z każdym skróceniem się telomeru rośnie ryzyko nowotworzenia, a komórka starzeje się. Im człowiek jest starszy, tym krótsze są jego telomery. Im silniejszy stres niekontrolowany, tym większe prawdopodobieństwo chorób nowotworowych, skrócenia telomerów i krótszego życia $[1,50]$.

Na długość telomerów bardzo duży wpływ mają: nasze emocje, traumy, zespół stresu pourazowego (PTSD Posttraumatic Stress Disorder), nieprawidłowa dieta i wiele innych. W 2017 r. wykonano metaanalizę obejmującą 16238 uczestników i wykazano, że im większy stres $\mathrm{w}$ dzieciństwie, tym krótsze telomery w wieku dojrzałym [51].

Są także dowody na działanie przeciwnych emocji pozytywnych. Odkrycie telomerazy - enzymu, którego działanie polega na odtwarzaniu telomerów - spowodowało, że inaczej patrzymy na udział pozytywnych emocji w leczeniu choroby nowotworowej. Do tej pory dowiedzieliśmy się, że im u dzieci więcej pozytywnych emocji i lepszych relacji z rodziną, tym dłuższe były ich telomery [52]. Pozytywne emocje, medytacja i aktywność ruchowa prowadzą już po 3 miesiącach do wzrostu telomerazy o $30 \%$ i wydłużenia się telomerów $[53,54]$. Warta podkreślenia jest konstatacja, że nie istnieje żaden lek na świecie, który doprowadziłby do podobnych efektów!

Kiedy jednak telomery są zbyt krótkie, uszkodzenie DNA może spowodować, że komórka wytworzy niefunkcjonalne białka, które mogą stać się niefunkcjonalnymi komórkami i ostatecznie przeobrazić się w komórki nowotworowe [55].

Istnieją dowody na to, że ćwiczenia fizyczne prowadzą do mniejszego wyczerpania telomerów i zmniejszenia ryzyka raka. Odbywa się to poprzez dwa mechanizmy: 
Many scientific papers prove that a sedentary lifestyle can result in shorter telomeres. On the other hand, there is evidence that intense physical activity elongates telomeres. This has been proven by research carried out among sports champions, who are found to have longer telomeres [57].

\section{STRESS, EPIGENETICS AND NEOPLASTIC DISEASE}

Epigenetics is a science that deals with "extragenetic heredity," i.e. it is not based on changes in genes themselves, but on chemical changes involving the attachment of different chemical groups to genes. Then the functioning of a given gene, i.e. the gene expression, is modified and so-called "cellular memory" (sometimes called "metabolic memory" or "epigenetic memory") is created [58].

It is now clear that epigenetics plays a key role in the maturation and aging of the body as well as in carcinogenesis, i.e. cancer formation.

Only in approximately $5-10 \%$ of cancer cases is a hereditary predisposition diagnosed. In such a case, cancer development depends primarily on incorrect information written in a genetic code, transmitted from generation to generation via a mutated gene. Usually, however, a predisposition itself is not enough to cause cancer formation. The cancer develops as a result of genetic conditions and environmental factors [59].

As early as in 2004, scientific reports on the formation of neoplastic diseases, in which epigenetic mechanisms play a role, began to appear. Epigenetic silencing of the MLH1 gene has been found to be associated with certain colorectal and rectal cancers [60].

Ten years later, in 2014, as a result of enormous development of scientific research in this field, the notion of epigenetic predisposition to various malignancies, including ovarian, stomach and colorectal cancer, was created [61].

DNA methylation in combination with the modification of histones and microRNA (miRNA) represent those mechanisms which are the most unstable in neoplastic disease. Innovative techniques applied in epigenetics, which involve investigating changes in gene expression without changes in the genetic code, provide a new dimension of tumour characterisation. This may affect diagnosis, prognosis and treatment. For instance, in 2019, a classifier based on DNA methylation was developed, which accurately distinguished the three most common subtypes of bone sarcomas. Given their clinically and histologically overlapping features as well as markedly different clinical management, this innovative methylation-based classifier may be a useful tool in differential diagnosis of bone sarcomas [62].

The identification of strong correlations between tumour epigenetics and its corresponding histological, radiographic and clinical information on the course of a specific neoplastic disease may ultimately help in making clinical decisions [63]. Among other things, the methy- zmniejszenie stresu oksydacyjnego i zmniejszenie przewlekłego zapalenia. Odwrotnie dzieje się u osób już chorych na raka. Ludzie podczas leczenia przeciwnowotworowego mogą cierpieć z powodu znacznego spadku jakości życia na skutek braku ruchu, co prowadzi dodatkowo do zwiększonego zużycia telomerów [56].

Wiele prac naukowych dowodzi, że siedzący tryb życia może skutkować krótszymi telomerami, a intensywna aktywność ruchowa wydłuża je. Dowodem na to są badania przeprowadzone wśród mistrzów sportu, u których stwierdza się dłuższe telomery [57].

\section{STRES, EPIGENETYKA I CHOROBA NOWOTWOROWA}

Epigenetyka to nauka zajmująca się „dziedziczeniem pozagenowym". Nazwa ta pochodzi stąd, że zmiany nie zachodzą w samych genach, ale dochodzi do zmian chemicznych polegających na przyłączaniu się różnych grup chemicznych do genów. Zmienia się funkcjonowanie danego genu, czyli jego ekspresja, i powstaje tzw. „pamięć komórkowa”, nazywana czasami ,pamięcią metaboliczną" lub ,pamięcią epigenetyczną" [58]. Obecnie wiadomo, że epigenetyka odgrywa kluczową rolę w dojrzewaniu i starzeniu się organizmu oraz $\mathrm{w}$ procesie nowotworzenia.

Jedynie w około 5-10\% przypadków zachorowań na nowotwór stwierdza się dziedzicznie uwarunkowaną predyspozycję. Rozwój nowotworu zależy wówczas przede wszystkim od nieprawidłowej informacji zapisanej w kodzie genetycznym, przekazywanej z pokolenia na pokolenie poprzez zmutowany gen. Jednak zwykle sama predyspozycja nie wystarczy, by wystąpiło zachorowanie na raka. Nowotwór rozwija się jako wypadkowa uwarunkowań dziedzicznych i czynników środowiskowych [59]. Już w 2004 r. zaczęły pojawiać się doniesienia naukowe na temat powstawania chorób nowotworowych, w których rolę odgrywają mechanizmy epigenetyczne. Dowiedziono, że epigenetyczne wyciszanie genu MLH1 jest związane z niektórymi nowotworami okrężnicy i odbytnicy [60]. Dziesięć lat później, w roku 2014, na skutek ogromnego postępu w rozwoju badań naukowych w tej dziedzinie powstało pojęcie predyspozycji epigenetycznych do zachorowania na różne nowotwory złośliwe, w tym raka jajnika, żołądka, jelita grubego [61].

Metylacja DNA, modyfikacja histonów i mikroRNA (miRNA) łącznie reprezentują te mechanizmy, które ulegają największemu rozregulowaniu w chorobie nowotworowej. Nowatorskie techniki stosowane w epigenetyce, polegające na badaniu zmian w ekspresji genów bez zmian w kodzie genetycznym, zapewniają nowy wymiar charakteryzowania nowotworów. Może to mieć wpływ na diagnostykę, prognozowanie i leczenie. Na przykład w 2019 r. opracowano klasyfikator oparty na metylacji DNA, który dokładnie rozróżnił trzy najczęstsze podtypy mięsaków kości. Biorąc pod uwagę ich pokrywające się klinicznie i histologicznie 
lation of gene promoters or acetylation of histones are observed in tumours [64,65]. The above-mentioned changes, called epigenetic markers, can be dynamically modified by histone acetyltransferases (HATs) and histone deacetylases (HDACs).

The knowledge of epigenetic mechanisms resulted in a different perspective on the diagnosis, prognosis and treatment of a neoplastic disease. Changes in DNA methylation occur at very early stages of carcinogenesis, hence this signal can be used for early oncological diagnosis. It has also been found that the deregulation of microRNA expression plays a significant role in human malignancies. Ten years ago, the identification of free circulating (in bioliquids) miRNAs led to great enthusiasm and motivation to develop non-invasive tests based on the expression of those small non-coding RNAs. Methodological and analytical variables are currently being developed. They may affect the final quantification of miRNAs to standardize analytical processes and enable successful translation of basic research results into clinical practice [66].

This has to do with the prognosis in particular types of cancer as well. The hypermethylation of certain genes in specific types of cancer correlates with a worse prognosis, while in others with a better prognosis. For instance, high methylation levels of protocadherin-10 (PCDH10) promoter may be useful in identifying patients with a high risk of pancreatic cancer progression [67].

In 2019, it was found that DNA methylation profiling can help to diagnose metastatic tumours from unknown primary sites: central nervous system primary cancers and other primary cancers [68].

Over the last two decades, it has been widely acknowledged that epigenetic modifications are involved in cancer initiation and progression, which motivated many researchers to include this new field in the development of anticancer drugs. Oncologists were particularly interested in compounds that inhibit epigenetic processes, mainly histone deacetylase (HDAC) inhibitors and DNA methyltransferases (DNMTs). It has turned out that they have anticancer effects, both in vitro and in vivo, and simultaneously show low toxicity. Oncologists believe that they can use them as new-generation cytotoxic agents $[69,70]$.

In recent years, several hundred trials have been conducted for clinical use of these compounds in monotherapy or in combination with other drugs, in patients with various types of haematological tumours and solid tumours. More than 15 HDAC inhibitors have already been included in the list of potential drugs $[71,72]$.

It is also emphasised that compounds which change epigenetic mechanisms are a new strategy for cancer chemoprevention and this new approach is becoming increasingly promising in human clinical research. Essential micronutrients, such as folic acid, vitamin $\mathrm{B} 12$, selenium and zinc, resveratrol as well as sulphate polyphenols, curcumin and others, belong to an ever-growing list of factors that have an effect on epigene- cechy oraz wyraźnie odmienne postępowanie kliniczne, nowatorski klasyfikator oparty na metylacji może stanowić przydatne narzędzie w diagnostyce różnicowej mięsaków kości [62].

Zidentyfikowanie silnych korelacji między epigenetyką guza a odpowiadającymi jej histologicznymi, radiograficznymi i klinicznymi informacjami o przebiegu konkretnej choroby nowotworowej, może ostatecznie pomóc w podejmowaniu decyzji klinicznych [63]. W guzach nowotworowych obserwuje się między innymi metylację promotorów genów lub acetylowanie histonów $[64,65]$. Powyższe zmiany, nazwane markerami epigenetycznymi, mogą być dynamicznie modyfikowane przez acetylotransferazy histonowe (HAT) i deacetylazy histonowe (HDAC).

Poznanie mechanizmów epigenetycznych zmieniło perspektywę spojrzenia na diagnostykę, rokowanie i leczenie choroby nowotworowej. Zmiany metylacji DNA zachodzą na bardzo wczesnych etapach nowotworzenia, dlatego sygnał ten może służyć wczesnej diagnostyce onkologicznej. Wykazano także, że deregulacja ekspresji mikroRNA odgrywa ważną rolę w ludzkich nowotworach złośliwych. Dziesięć lat temu identyfikacja wolnych, krążących miRNA w biopłynach wywołała wielki entuzjazm i motywację do opracowania nieinwazyjnych testów opartych na ekspresji tych małych niekodujących RNA. Obecnie opracowuje się zmienne metodologiczne i analityczne, które mogą wpływać na ostateczną kwantyfikację miRNA po to, aby stworzyć standaryzacje procesów analitycznych i umożliwić pomyślne przeniesienie wyników badań podstawowych do praktyki klinicznej [66].

Ma to również związek z rokowaniem w poszczególnych typach nowotworu. Hipermetylacja pewnych genów w określonych typach nowotworów koreluje z gorszym rokowaniem, w innych zaś z rokowaniem lepszym. Przykładem są wysokie poziomy metylacji promotora protokadheryny 10 (PCDH10), które moga być przydatne do identyfikacji pacjentów z wysokim ryzykiem progresji raka trzustki [67].

W 2019 r. wykazano, że profilowanie metylacji DNA może pomóc w diagnozowaniu nowotworów przerzutowych z nieznanych pierwotnych miejsc, nowotworów pierwotnych ośrodkowego układu nerwowego i innych pierwotnych nowotworów [68].

W ciągu ostatnich dwóch dziesięcioleci powszechnie uznano, że modyfikacje epigenetyczne biorą udział w inicjacji i progresji nowotworu, co zmotywowało wielu badaczy do włączenia tej nowej dziedziny do opracowywania leków przeciwnowotworowych. Onkolodzy zainteresowali się $\mathrm{w}$ związku $\mathrm{z}$ tym przede wszystkim związkami, które hamują procesy epigenetyczne, głównie inhibitorami deacetylaz histonowych (HDAC) oraz metylotransferazami DNA (DNMT). Okazało się bowiem, że mają one działanie przeciwnowotworowe zarówno in vitro, jak i in vivo, a jednocześnie wykazują małą toksyczność. Onkolodzy uważają, że można stosować je jako cytostatyki nowej generacji $[69,70]$. 
tics, as new mechanisms of chemoprevention. They can change the gene expression and affect the progression of cancer $[73,74,75]$.

\section{DISCUSSION}

There is also another point of view that does not prove the link between stress and neoplastic diseases.

Kruk et al. presented the current status of their studies, among which - in addition to the evidence of a link between psychological stress and cancer risk/cellular ageing - they also presented evidence of the absence of such a link. Kruk analysed ten databases on medical research, including 14 cohort studies and 12 follow-up studies. She concluded that psychosocial factors can be considered as risk factors for the cellular ageing, but not for all types of cancer [76].

Schraub (et al.) analysed 18 publications that did not show a link between psychological factors and cancer risk. He concluded that none of those studies showed a significant link between personality traits and cancer risk. According to him, life events, personality traits or depression cannot be proven with certainty that they play a role in cancer development [77].

Denario (et al.), likewise, found a lack of links in her meta-analysis [78]. There are more articles that question the link between stress and neoplastic diseases, but there are also many publications that prove this link. It should be emphasised, though, that the knowledge contained in this article - which is a synthesis of various research results, particularly the most recent ones is the basis for inferring about the occurrence of stress-related links with neoplastic diseases.

This is proved by the mechanisms of stress and its effects on many different levels, which have been investigated and described. For instance, the identification of epigenetic mechanisms has resulted in a different perspective on hereditary cancer. In clinical analyses, these aspects are not taken into consideration at all. In order to carry out research on this subject in people, it would also be necessary to take into account the type of stress the patient is under - controlled or uncontrolled. Alas, this is not examined at any research centre either. After all, during a neoplastic disease, the transition to a state of controlled stress strongly supports therapy, increasing the chances of survival or even recovery.

A lifestyle change is most often a prerequisite for stress management. Stress management, physical activity and healthy eating can even cause changes at the epigenome level, and scientific research shows that we can then defeat many hereditary traumas, even reducing the likelihood of the formation of various malignancies.

Given all the above-mentioned factors, whose cancer-promoting effects have already been recognised in scientific research, it can be expected that in people who are under severe chronic stress, the prevalence of neoplastic diseases will increase if they fail to manage their stress and trauma and they remain under uncontrolled stress.
W ostatnich latach podjęto kilkaset prób klinicznego zastosowania tych związków w monoterapii lub w skojarzeniu z innymi lekami u chorych z różnego typu nowotworami hematologicznymi oraz guzami litymi. Już ponad 15 inhibitorów HDAC znalazło się na liście potencjalnych leków [71,72].

Podkreśla się także, że związki, które zmieniają mechanizmy epigenetyczne, stanowią nową strategię chemoprewencji nowotworów i to nowe podejście zaczyna być coraz bardziej obiecujące w badaniach klinicznych u ludzi. Niezbędne mikroskładniki odżywcze, takie jak kwas foliowy, witamina B12, selen i cynk, resweratrol, a także siarczanowe polifenole, kurkumina $\mathrm{i}$ inne, należą do rosnącej listy czynników, które wpływają na epigenetykę jako nowe mechanizmy chemoprewencji. Mogą bowiem zmieniać ekspresję genów i wpływać na postęp raka $[73,74,75]$.

\section{DYSKUSJA}

Wśród badaczy istnieje także inne stanowisko, które nie potwierdza związku stresu z chorobami nowotworowymi.

Kruk i wsp. przedstawili aktualny stan badań, prezentując oprócz dowodów na istnienie związku między stresem psychicznym a ryzykiem raka i procesem starzenia się komórek, również dowody na brak takiej korelacji. Autorka poddała analizie dziesięć baz danych dotyczących badań medycznych, w tym 14 badań kohortowych i 12 badań kontrolnych. Sformułowała wniosek, że czynniki psychospołeczne można uznać za czynniki ryzyka w procesie starzenia się komórek, ale nie wszystkich rodzajów raka [76].

Schraub i wsp. dokonali przeglądu 18 publikacji, które nie wykazały związku między czynnikami psychologicznymi a ryzykiem raka. Stwierdzili, że żadne z tych badań nie wykazało istotnego związku między cechami osobowości a ryzykiem raka i że nie można z całą pewnością dowieść, że wydarzenia życiowe, cechy osobowości lub depresja odgrywają rolę w wystąpieniu raka [77]

Brak związków wykazali również w swojej metaanalizie Denario i wsp. [78]. Artykułów, które kwestionują związek stresu z chorobami nowotworowymi, jest więcej, ale badań potwierdzających taki związek jest również wiele. Należy jednak podkreślić, że wiedza zawarta $\mathrm{w}$ prezentowanym artykule, będąca syntezą różnorodnych wyników badań, szczególnie zaś tych najnowszych, jest podstawą wnioskowania o istnieniu związków stresu z chorobami nowotworowymi.

Dowodzą tego zbadane i opisywane mechanizmy stresu i jego skutki na wielu różnych poziomach. Na przykład, poznanie mechanizmów epigenetycznych zmieniło perspektywę spojrzenia na dziedziczenie raka. Te aspekty nie są w ogóle brane pod uwagę $\mathrm{w}$ analizach klinicznych. Aby przeprowadzić badania na ten temat u ludzi, należałoby wziąć także pod uwagę fakt, z jakim typem stresu mamy do czynienia u pacjenta - kontrolowanym czy niekontrolowanym. Niestety, tego również aktual- 
However, if they manage their stress and reach in a state of controlled stress, one can even expect a decrease in the prevalence of neoplastic diseases, as evidenced by all the scientific studies quoted in this article.

\section{Author's contribution}

Study design - J. Jośko-Ochojska (100\%)

Data collection - J. Jośko-Ochojska (70\%), R. Brus (30\%)

Manuscript preparation - J. Jośko-Ochojska (70\%), R. Brus (30\%)

Literature research - J. Jośko-Ochojska (70\%), R. Brus (30\%) nie nie poddaje się analizie w żadnym ośrodku badawczym. A przecież w trakcie choroby nowotworowej przejście w stan stresu kontrolowanego zdecydowanie wspomaga terapię, zwiększając szansę na przeżycie lub nawet wyzdrowienie.

Najczęściej warunkiem przejęcia kontroli nad stresem jest zmiana dotychczasowego stylu życia. Radzenie sobie ze stresem, aktywność ruchowa i zdrowe odżywianie się są w stanie spowodować nawet zmiany na poziomie epigenomu, a badania naukowe dowodzą, że możemy wtedy uporać się z licznymi odziedziczonymi traumami, zmniejszając tym samym prawdopodobieństwo zachorowania na różne nowotwory złośliwe.

Wziąwszy pod uwagę wszystkie opisane czynniki, których działanie pronowotworowe zostało już uznane w badaniach naukowych, można spodziewać się, że u ludzi, którzy są poddawani silnym, przewlekłym stresom, częstość zachorowań na choroby nowotworowe będzie wzrastała, jeśli nie poradzą sobie ze swoim stresem czy traumą i pozostaną w sytuacji stresu niekontrolowanego. Jeśli jednak będą radzili sobie ze stresem i osiągną stan stresu kontrolowanego, wówczas można oczekiwać nawet spadku zachorowań na nowotwory, czego dowodem są wszystkie badania naukowe cytowane $\mathrm{w}$ prezentowanym artykule.

\section{REFERENCES}

1. Jośko-Ochojska J., Ochojski A. Rozmowy przy kawie. O stresie, lęku i traumie. Wydawnictwo Andrzej Ochojski. Rybnik 2019.

2. Mason J.W. A re-evaluation of the concept of 'non-specifity' in stress theory. J. Psychiatr. Res. 1971; 8(3): 323-333, doi: 10.1016/0022-3956(71)90028-8.

3. Borczykowska-Rzepka M. Satysfakcja z życia matek dzieci z zaburzeniami ruchowymi pochodzenia ośrodkowego oraz dzieci z mózgowym porażeniem dziecięcym. Rozprawa doktorska. Śląski Uniwersytet Medyczny w Katowicach. Katowice 2008

4. Winchester D.P. Breast cancer. PMPH-USA. 2006; 607: 3-4

5. Lutgendorf S.K., Sood A.K. Biobehavioral factors and cancer progression physiological pathways and mechanisms. Psychosom. Med. 2011; 73(9): 724-30, doi: 10.1097/PSY.0b013e318235be76.

6. Lillberg K., Verkasalo P.K., Kaprio J., Teppo L., Helenius H., Koskenvuo M. Stressful life events and risk of breast cancer in 10,808 women: a cohort study. Am. J. Epidemiol. 2003; 157(5): 415-423, doi: 10.1093/aje/kwg002.

7. Yang T., Qiao Y., Xiang S., Li W., Gan Y., Chen Y. Work stress and the risk of cancer: A meta-analysis of observational studies. Int. J. Cancer 2019; 144(10): 2390-2400, doi: 10.1002/ijc.31955.

8. Al-Wadei H.A., Ullah M.F., Al-Wadei M.H. Intercepting neoplastic progression in lung malignancies via the beta adrenergic $(\beta-A R)$ pathway: implications for anti-cancer drug targets. Pharmacol. Res. 2012; 66(1): 33-40, doi: 10.1016/j.phrs.2012.03.014

9. Lee J.W., Shahzad M.M., Lin Y.G., Armaiz-Pena G., Mangala L.S., Han H.D., Kim H.S., Nam E.J., Jennings N.B., Halder J., Nick A.M., Stone R.L. Lu C., Lutgendorf S.K., Cole S.W., Lokshin A.E, Sood A.K. Surgical stress promotes tumor growth in ovarian carcinoma. Clin. Cancer Res. 2009; 15(8): 2695-2702, doi: 10.1158/1078-0432.CCR-08-2966.

10. Pu J., Bai D., Yang X., Lu X., Xu L., Lu J. Adrenaline promotes cell proliferation and increases chemoresistance in colon cancer HT29 cells through induction of miR-155. Biochem. Biophys. Res. Commun. 2012; 428(2): 210 -215 , doi: 10.1016/j.bbrc.2012.09.126.

11. Schuller H.M., Al-Wadei H.A., Ullah M.F., Plummer H.K. 3rd: Regulation of pancreatic cancer by neuropsychological stress responses: a novel target for intervention. Carcinogenesis. 2012; 33(1): 191-196, doi: 10.1093/carcin/ bgr 251 .

12. Wong H.P., Ho J.W., Koo M.W., Yu L., Wu W.K., Lam E.K., Tai E.K., Ko J.K., Shin V.Y., Chu K.M., Cho C.H. Effects of adrenaline in human colon adenocarcinoma HT-29 cells. Life Sci. 2011; 88(25-26): 1108-1112, doi: 10.1016/j.1fs.2011.04.007.

13. Chida Y., Hamer M., Wardle J., Steptoe A. Do stress-related psychosocia factors contribute to cancer incidence and survival? Nat. Clin. Pract. Oncol. 2008; 5(8): 466-475, doi: 10.1038/ncponc1134.
14. Palm D., Lang K., Niggemann B., Drell T.L., Masur K., Zaenker K.S., Entschladen F. The norepinephrine-driven metastasis development of PC-3 human prostate cancer cells in BALB/c nude mice is inhibited by beta-blockers. Int. J. Cancer 2006; 118(11): 2744-2749, doi: 10.1002/ijc.21723.

15. Armaiz-Pena G.N., Cole S.W., Lutgendorf S.K., Sood A.K. Neuroendocrine influences on cancer progression. Brain Behav. Immun. 2013; 30 Suppl(Suppl): S19-S25, doi: 10.1016/j.bbi.2012.06.005.

16. Surman M., Janik M.E. Stres i jego molekularne konsekwencje w rozwoju choroby nowotworowej. Postepy Hig. Med. Dosw. (online) 2017; 71(0): 485-499, doi: 10.5604/01.3001.0010.3830.

17. Flint M.S., Baum A., Episcopo B., Knickelbein K.Z., Liegey Dougall A.J., Chambers W.H., Jenkins F.J. Chronic exposure to stress hormones promotes transformation and tumorigenicity of 3T3 mouse fibroblasts. Stress 2013; 16(1): 114-121, doi: 10.3109/10253890.2012.686075.

18. Powe D.G., Voss M.J., Zanker K.S., Habashy H.O., Green A.R., Ellis I.O., Entschladen F. Beta-blocker drug therapy reduces secondary cancer formation in breast cancer and improves cancer specific survival. Oncotarget. 2010; 1(7): 628-638, doi: 10.18632/oncotarget.101009.

19. Melhem-Bertrandt A., Chavez-Macgregor M., Lei X., Brown E.N., Lee R.T, Meric-Bernstam F., Sood A.K., Conzen S.D., Hortobagyi G.N., Gonzalez-Angulo A.M. Beta-blocker use is associated with improved relapse-free survival in patients with triple-negative breast cancer. J. Clin. Oncol. 2011; 29(19): 2645-2652, doi: 10.1200/JCO.2010.33.4441

20. Smith C.J., Minas T.Z., Ambs S. Analysis of Tumor Biology to Advance Cancer Health Disparity Research. Am. J. Pathol. 2018; 188(2): 304-316, doi: 10.1016/j.ajpath.2017.06.019.

21. Tilan J., Kitlinska J. Sympathetic neurotransmitters and tumor angiogenesis - link between stress and cancer progression. J. Oncol. 2010; 2010: 539706, doi: 10.1155/2010/539706.

22. Weisenrieder J.S., Neighbors J.D., Mailman R.B., Hohl R.J. Cancer and dopamine D2 receptor: A pharmacological perspective. The Journal of Pharmacology and Experimental Therapeutics. 2019; 370(1): 111-126, doi: 10.1124/ jpet.119.256818.

23. Engwa G.A., Ayuk E.L., Igbojekwe B.U., Unaegbu M. Potential Antioxidant Activity of New Tetracyclic and Pentacyclic Nonlinear Phenothiazine Derivatives. Biochem. Res. Int. 2016: 9896575 , doi: 10.1155/2016/9896575. 24. Ghinet A., Moise I.M., Rigo B., Homerin G., Farce A., Dubois J., Bicu E. Studies on phenothiazines: New microtubule-interacting compounds with phenothiazine A-ring as potent antineoplastic agents. Bioorg. Med. Chem. 2016; 24(10): 2307-2317, doi: 10.1016/j.bmc.2016.04.001.

25. Wu B.J., Lin C.H., Tseng H.F., Liu W.M., Chen W.C., Huang L.S., Sun H.J., Chiang S.K., Lee S.M. Validation of the Taiwanese Mandarin version 
of the Personal and Social Performance scale in a sample of 655 stable schizophrenic patients. Schizophr. Res. 2013; 146(13): 34-39, doi: 10.1016/j. schres.2013.01.036.

26. Gryz M., Lehner M., Wisłowska-Stanek A., Płaźnik A. Funkcjonowanie układu dopaminergicznego $\mathrm{w}$ warunkach stresu - poszukiwanie podstaw różnic indywidualnych, badania przedkliniczne. Psychiatr. Pol 2018; 52(3): 459-470. 27. Lehner M.H., Taracha E., Kaniuga E., Wisłowska-Stanek A., Wróbel J., Sobolewska A., Turzyńska D., Skórzewska A., Płaźnik A. Highanxiety rats are less sensitive to the rewarding effects of amphetamine on $50 \mathrm{kHz}$ USV. Behav. Brain Res. 2014; 275: 234-242, doi: 10.1016/j.bbr.2014.09.011.

28. Hill M.N., Hellemans K.G.C., Verma P., Gorzalka B.B., Weinberg J. Neurobiology of chronic mild stress: Parallels to major depression. Neurosci. Biobehav. Rev. 2012; 36(9): 2085-2117, doi: 10.1016/j.neubiorev.2012.07.001.

29. Marchewka Z., Gielniak M., Piwowar A. Rola wybranych mediatorów procesu zapalnego w patogenezie chorób nowotworowych. Postepy Hig. Med. Dosw. (online) 2018; 72: 175-183.

30. Paulsen O., Laird B., Aass N., Lea T., Fayers P., Kaasa S., Klepstad P. The relationship between pro-inflammatory cytokines and pain, appetite and fatigue in patients with advanced cancer. PLoS One 2017; 12(5): e0177620, doi: 10.1371/journal.pone. 0177620 .

31. Todorović-Raković N., Milovanović J. Interleukin-8 in breast cancer progression. J. Interferon Cytokine Res. 2013; 33(10): 563-570, doi: 10.1089/ jir.2013.0023.

32. Brat D J., Bellail A.C., Van Meir E.G. The role of interleukin-8 and its receptors in gliomagenesis and tumoral angiogenesis. Neuro Oncol. 2005; 7(2): 122-133, doi: $10.1215 /$ S1152851704001061.

33. Irwin M. Immune correlates of depression. Adv. Exper. Med. Biol. 1999; 461: 1-24, doi: 10.1007/978-0-585-37970-8 1 .

34. Liu B., Li Z., Mahesh S.P., Pantanelli S., Hwang F.S., Siu W.O., Nussenblatt R.B. Glucocorticoid-induced tumor necrosis factor receptor negatively regulates activation of human primary natural killer (NK) cells by blocking proliferative signals and increasing NK cell apoptosis. J. Biol. Chem. 2008; 283(13) 8202-8210, doi: 10.1074/jbc.M708944200.

35. Hanahan D., Weinberg R.A. The hallmarks of cancer. Cell 2000; 100(1): 57-70, doi: 10.1016/s0092-8674(00)81683-9.

36. Hassan S., Karpova Y., Baiz D., Yancey D., Pullikuth A., Flores A., Registe T., Cline J.M., D'Agostino R Jr., Danial N., Datta S.R., Kulik G. Behaviora stress accelerates prostate cancer development in mice. J. Clin. Invest. 2013; 123(2): $874-886$, doi: $10.1172 /$ JCI63324

37. Nagaraja A.S., Armaiz-Pena G.N., Lutgendorf S.K., Sood A.K. Why stress is BAD for cancer patients. J. Clin. Invest. 2013; 123(2): 558-560, doi: 10.1172/JCI67887.

38. Sastry K.S., Karpova Y., Prokopovich S., Smith A.J., Essau B., Gersappe A., Carson J.P., Weber M.J., Register T.C., Chen Y.Q., Penn R.B., Kulik G. Epinephrine protects cancer cells from apoptosis via activation of cAMP-dependent protein kinase and BAD phosphorylation. J. Biol. Chem. 2007; 282(19): 14094-14100, doi: 10.1074/jbc.M611370200.

39. Thaker P.H., Han L.Y., Kamat A.A., Arevalo J.M., Takahashi R., Lu C., Jennings N.B., Armaiz-Pena G., Bankson J.A., Ravoori M., Merritt W.M., Lin Y.G., Mangala L.S., Kim T.J., Coleman R.L., Landen C.N., Li Y., Felix E., Sanguino A.M., Newman R.A., Lloyd M., Gershenson D.M., Kundra V., Lopez-Berestein G., Lutgendorf S.K., Cole S.W., Sood A.K. Chronic stress promotes tumor growth and angiogenesis in a mouse model of ovarian carcinoma. Nat. Med. 2006; 12(8): 939-944, doi: 10.1038/nm1447.

40. Shan T., Ma J., Ma Q., Guo K., Guo J., Li X., Li W., Liu J., Huang C., Wang F., Wu E. $\beta 2$-AR-HIF-1 $\alpha$ : a novel regulatory axis for stress-induced pancreatic tumor growth and angiogenesis. Curr. Mol. Med. 2013; 13(6): 1023-1034, doi: $10.2174 / 15665240113139990055$

41. Campbell J.P., Karolak M.R., Ma Y., Perrien D.S., Masood-Campbell S.K., Penner N.L., Munoz S.A., Zijlstra A., Yang X., Sterling J.A., Elefteriou F. Stimulation of host bone marrow stromal cells by sympathetic nerves promote breast cancer bone metastasis in mice. PLoS Biol. 2012; 10(7): e1001363, doi: 10.1371/journal.pbio. 1001363 .

42. Sloan E.K., Priceman S.J., Cox B.F., Yu S., Pimentel M.A., Tangkanangnukul V., Arevalo J.M., Morizono K., Karanikolas B.D., Wu L., Sood A.K., Cole S.W. The sympathetic nervous system induces a metastatic switch in primary breast cancer. Cancer Res. 2010; 70(18): 7042-7052, doi: 10.1158/0008-5472. CAN-10-0522.

43. Ji H., Liu N., Li J., Chen D., Luo D., Sun Q., Yin Y., Liu Y., Bu B., Chen $\mathrm{X}$, Li J. Oxytocin involves in chronic stress-evoked melanoma metastasis via $\beta$-arrestin 2-mediated ERK signaling pathway. Carcinogenesis 2019; 40(11): 1395-1404, doi: 10.1093/carcin/bgz064.

44. Ścibior-Bentkowska D., Czeczot H. Cancer cells and oxidative stress. Postepy Hig. Med. Dosw. (online) 2009; 63: 58-72.

45. Behrend L., Henderson G., Zwacka R.M. Reactive oxygen species in oncogenic transformation. Biochem. Soc. Trans. 2003; 31 (Pt 6): 1441-1444, doi 10.1042/bst0311441

46. Zaremba T., Oliński R. Oksydacyjne uszkodzenia DNA - ich analiza oraz znaczenie kliniczne. Postępy Biochemii 2010; 56(2): 124-138.

47. Sawicka E., Lisowska A., Kowal P., Długosz A. Rola stresu oksydacyjnego w raku pęcherza moczowego. Postepy Hig. Med. Dosw. (online) 2015; 69: 744-752, doi: 10.5604/17322693.1160361.
48. Malins D.C., Gunselman S.J. Fourier-transform infrared spectroscopy and gas chromatography-mass spectrometry reveal a remarkable degree of structural damage in the DNA of wild fish exposed to toxic chemicals. Proc. Natl. Acad. Sci. USA 1994; 91(26): 13038-13041, doi: 10.1073/pnas.91.26.13038. 49. Shammas M.A. Telomeres, lifestyle, cancer, and aging. Curr. Opin. Clin. Nutr. Metab. Care 2011; 14(1): 28-34. doi: 10.1097/MCO.0b013e32834121b1. 50. Blackburn E., Epel E. Telomeres and Adversity: Too Toxic to Ignore. Nature 2012; 490(7419): 169-171, doi: 10.1038/490169a.

51. Hanssen L.M., Schutte N.S., Malouff J.M., Epel E.S. The Relationship Between Childhood Psychosocial Stressor Level and Telomere Length: A Meta-Analysis. Health Psychol. Res. 2017; 16; 5(1): 6378, doi: 10.4081/ hpr.2017.6378.

52. Robles T.F., Carroll J.E., Bai S., Reynolds B.M., Esquivel S., Repetti R.L. Emotions and family interactions in childhood: Associations with leukocyte telomere length emotions, family interactions, and telomere length. Psychoneuroendocrinology 2016; 63: 343-350, doi: 10.1016/j.psyneuen.2015.10.018. 53. Jacobs T.L., Epel E.S., Lin J., Blackburn E.H., Wolkowitz O.M., Bridwell D.A., Zanesco A.P., Aichele S.R., Sahdra B.K., MacLean K.A., King B.G., Shaver P.R., Rosenberg E.L., Ferrer E., Wallace B.A., Saron C.D. Intensive meditatin training, immune cell telomerase activity, and psychological mediators. Psychoneuroendocrinology 2011; 36(5): 664-681, doi: 10.1016/j.psyneuen.2010.09.010

54. Ornish D., Lin J., Daubenmier J., Weidner G., Epel E., Kemp C., Magbanua M.J.M., Marlin R., Yglecias L., Carroll P.R., Blackburn E. H. Increased telomerase activity and comprehensive lifestyle changes: a pilot study. Lancet Oncology 2008; 9(11): 1048-1057, doi: 10.1016/S1470-2045(08)70234-1.

55. Maciejowski J., de Lange T. Telomeres in cancer: tumour suppression and genome instability. Nat. Rev. Mol. Cell Biol. 2017; 18(3): 175-186, doi: 10.1038/nrm.2016.171.

56. Nomikos N.N., Nikolaidis P.T., Sousa C.V., Papalois A.E., Rosemann T., Knechtle B. Exercise, Telomeres, and Cancer: "The Exercise-Telomere Hypothesis". Front Physiol 2018; 9: 1798, doi: 10.3389/fphys.2018.01798.

57. Simoes H.G., Sousa C.V., Dos Santos Rosa T., da Silva Aguiar S., Deus L.A., Rosa ECCC., Amato A.A., Andrade R.V. Longer Telomere Length in Elite Master Sprinters: Relationship to Performance and Body Composition. Int. J. Sports Med. 2017; 38(14): 1111-1116, doi: 10.1055/s-0043-120345.

58. Jośko-Ochojska J. Dziedziczenie traumy. Epigenetyczny „list” do przyszłych pokoleń. W: Medyczne i społeczne aspekty traumy [Jośko-Ochojska J. Inheritance of trauma. Epigenetic "letter" to future generations. In: Medical and social aspects of trauma]. Red. J. Jośko-Ochojska. Sląski Uniwersytet Medyczny. Katowice 2016

59. http://onkologia.org.pl/nowotwory-genetyczne/ [dostęp 15.09.2020]

60. Egger G., Liang G., Aparicio A., Jones P.A. Epigenetics in human disease and prospects for epigenetic therapy. Nature 2004; 429(6990): 457-463, doi: 10.1038/nature02625

61. Yamaguchi K., Matsumura N., Mandai M., Baba T., Konishi I., Murphy S.K. Epigenetic and genetic dispositions of ovarian carcinomas. Oncoscience 2014; 1(9): 574-579, doi: 10.18632/oncoscience.82.

62. Wu S.P., Cooper B.T., Bu F., Bowman C.J., Killian J.K., Serrano J., Wang S., Jackson T.M., Gorovets D., Shukla N., Meyers P.A., Pisapia D.J., Gorlick R., Ladanyi M., Thomas K., Snuderl M., Karajannis M.A. DNA Methylation-Based Classifier for Accurate Molecular Diagnosis of Bone Sarcomas. JCO Precis Oncol. 2017; doi: 10.1200/PO.17.00031.

63. Hauser B.M., Lau A., Gupta S., Bi W.L., Dunn I.F. The Epigenomics of Pituitary Adenoma. Front Endocrinol. (Lausanne) 2019; 14(10): 290, doi: 10.3389/fendo.2019.00290

64. Baylin S.B., Jones P.A. A decade of exploring the cancer epigenome biological and translational implications. Nat. Rev. Cancer 2011; 23; 11(10): 726-734, doi: $10.1038 / \mathrm{nrc} 3130$

65. Jenuwein T., Allis C.D. Translating the histone code. Science 2001; 293(5532): 1074-1080, doi: 10.1126/science.1063127.

66. Andersen G.B., Tost J. Circulating miRNAs as Biomarker in Cancer. Recent Results Cancer Res. 2020; 215: 277-298, doi: 10.1007/978-3-030-26439-0_15. 67. Curia M.C., Fantini F., Lattanzio R., Tavano F., Di Mola F., Piantelli M., Battista P., Di Sebastiano P., Cama A. High methylation levels of PCDH10 predict poor prognosis in patients with pancreatic ductal adenocarcinoma. BMC Cancer 2019; 19(1): 452, doi: 10.1186/s12885-019-5616-2.

68. Orozco J.I.J., Manughian-Peter A.O., Salomon M.P., Marzese D.M. Epigenetic Classifiers for Precision Diagnosis of Brain Tumors. Epigenet Insights. 2019; 12: 2516865719840284, doi: 10.1177/2516865719840284

69. Stepulak A., Stryjecka-Zimmer M., Kupisz K., Polberg K. Inhibitory deacetylaz histonów jako potencjalne cytostatyki nowej generacji. Postepy Hig. Med. Dosw. 2005; 59: 68-74

70. Vigushin D.M., Coombes R.C. Histone deacetylase inhibitors in cancer treatment. Anticancer Drugs 2002; 13(1): 1-13, doi: 10.1097/00001813200201000-00001.

71. Kim H.J., Bae S.C. Histone deacetylase inhibitors: molecular mechanisms of action and clinical trials as anti-cancer drugs. Am. J. Transl. Res. 2011; 3(2): 166-179.

72. Grabarska A., Dmoszyńska-Graniczka M., Nowosadzka E., Stepulak A. Inhibitory deacetylaz histonów - mechanizmy działania na poziomie molekularnym i zastosowania kliniczne. Postepy Hig. Med. Dosw. 2013; 67: 722-735. 
73. Li L.C., Carroll P.R., Dahiya R. Epigenetic changes in prostate cancer: implication for diagnosis and treatment. J. Natl. Cancer Inst. 2005; 97(2): 103 115, doi: $10.1093 / \mathrm{jnci} / \mathrm{dji} 010$

74. Ho E., Beaver L.M., Williams D.E., Dashwood R.H. Dietary Factors and Epigenetic Regulation for Prostate Cancer Prevention. Adv. Nutr. 2011; 2(6) 497-510, doi: 10.3945/an.111.001032.

75. Shukla S., Penta D., Mondal P., Meeran S.M. Epigenetics of Breast Cancer: Clinical Status of Epi-drugs and Phytochemicals. Adv. Exp. Med. Biol. 2019; 1152: 293-310, doi: 10.1007/978-3-030-20301-6 16.
76. Kruk J., Aboul-Enein B.H, Bernstein J., Gronostaj M. Psychological Stress and Cellular Aging in Cancer: A Meta-Analysis. Oxid. Med. Cell. Longev. 2019: 2019: 1270397 , doi: $10.1155 / 2019 / 1270397$.

77. Schraub S., Sancho-Garnier H., Velten M. Should psychological events be considered cancer risk factors? Rev. Epidemiol. Sante Publique 2009; 57(2): 113-123, doi: 10.1016/j.respe.2008.12.012.

78. Denaro N., Tomasello L., Russi E.G. Cancer and stress: what's matter? From epidemiology: the psychologist and oncologist point of view. Journal of Cancer Therapy \& Research 2014; 3(6): 1-11, doi: 10.7243/2049-7962-3-6. 